V Seminário Anual Científico e Tecnológico | Bio-Manguinhos

\title{
BIO 05 - Clonagem, expressão e purificação do domínio externo da proteína de membrana externa A (OmpAExt) de Acinetobacter baumannii
}

Anna Erika Vieira de Araújo ${ }^{1 *}$; Geiseane da Conceição Corrêa ${ }^{1}$; Marcele da Silva Tamara1; Haroldo Cid da Silva Junior' ${ }^{1}$ José Procópio Moreno Senna ${ }^{1}$.

1 Bio-Manguinhos / Fiocruz.

\section{Introdução:}

Acinetobacter baumannii é um patógeno nosocomial oportunista presente mundialmente, com alta incidência em unidades de tratamento intensivo e de difícil eliminação do ambiente hospitalar. A crescente multirresistência deste patógeno limita a terapêutica e abre espaço para a busca de novos tratamentos. Trabalhos anteriores mostram que a proteína de membrana externa A (OmpA) possui alta imunogenicidade, porém dada a sua natureza estrutural, apenas uma parte desta proteína está acessível externamente. Ao direcionar a resposta imune a um alvo mais específico é esperado um aumento na eficiência desta resposta, já que todos os anticorpos gerados serão direcionados para epítopos presentes na porção exposta da proteína, aprimorando a resposta imune para o uso em imunoterapias.

\section{Objetivo:}

Clonar, expressar e purificar o domínio externo da OmpA (rOmpAExt).

\section{Metodologia:}

A partir da análise computacional da estrutura da OmpA foi isolada uma sequência parcial de 303 bp, correspondente a estruturas externas à membrana. Este gene foi amplificado por PCR utilizando o DNA genômico da cepa de A. baumannii ATCC 19606 e clonada no vetor pET28a. Após a análise de sequenciamento dos clones obtidos, os plasmídeos recombinantes foram usados para transformar cepas de Escherichia coli BL-21 (DE3). Para expressão, as células foram cultivadas em meio LB a $37{ }^{\circ} \mathrm{C}$, diminuindo a temperatura para $30{ }^{\circ} \mathrm{C}$ durante a indução com IPTG na fase exponencial de cultivo. As células foram recuperadas, lisadas por sonicação e a proteína recombinante purificada por cromatografia de afinidade em coluna de níquel. Ensaios de ELISA e Western Blot foram realizados a fim de analisar a antigenicidade de rOmpAext frente ao soro policlonal antirOmpA produzido anteriormente em camundongos. 


\section{Resultado:}

As análises por SDS-PAGE mostraram a expressão de uma proteína com massa molecular de aproximadamente $14 \mathrm{kDa}$, sendo que boa parte desta foi expressa na forma solúvel. Após a etapa de purificação, foi possível obter uma fração da proteína de interesse com homogeneidade aceitável. Os imunoensaios demonstraram que o fragmento rOmpAExt foi reconhecido por anticorpos anti-rOmpA.

\section{Conclusão:}

Este estudo mostrou que foi possível obter a proteína recombinante referente à parte externa da OmpA de A. baumannii. A rOmpAExt foi obtida de forma solúvel a partir da expressão em Escherichia coli e ainda foi identificada pelos anticorpos policlonais antirOmpA, demonstrando que essa região deve possuir epítopos imunogênicos. Anticorpos capazes de se ligar a essa proteína rOmpAExt devem ter a habilidade de reconhecer o patógeno de forma íntegra, pois significa que se ligarão à superfície bacteriana, diferentemente de sua forma não modificada (rOmpA) que possui diversos epítopos imunogênicos que não estão expostos. Esta proteína pode servir como ferramenta para a obtenção de anticorpos monoclonais, ou no desenvolvimento de vacinas contra este patógeno.

Palavras-chave: Acinetobacter baumannii; proteína recombinante; imunoterapias 